\title{
CAUSALITY BETWEEN FEMALE FERTILITY AND FEMALE LABOUR FORCE PARTICIPATION IN ASEAN-5
}

\author{
Thirunaukarasu Subramaniam ${ }^{1}$, Mazlan Majid ${ }^{2}$, \\ Nanthakumar Loganathan ${ }^{3} \&$ Evelyn S Devadason ${ }^{4}$ \\ 1,2Department of Southeast Asian Studies, Faculty of Arts and Social Sciences \\ University of Malaya, Kuala Lumpur, Malaysia \\ ${ }^{3}$ Azman Hashim International Business School \\ Universiti Teknologi Malaysia, Johor Bahru, Malaysia \\ ${ }^{4}$ Department of Economics, Faculty of Economics and Administration \\ University of Malaya, Kuala Lumpur, Malaysia \\ (stkarasu@um.edu.my, mazlanmajid@um.edu.my, \\ n4nantha@yahoo.com, evelyns@um.edu.my) \\ DOI: https://doi.org/10.22452/jati.vol23no1.3
}

\begin{abstract}
Researches on whether female fertility determines labour force participation or vice versa have reached mixed results. A high participation of females in the labour market can limit the family size, and conversely, low female fertility can free up their time and increase their participation in the labour market. As such, this paper sets out to answer the question of "What causes what?" Having established the existence of cointegration for Malaysia, Singapore, Thailand, the Philippines and Indonesia (hereafter ASEAN-5) using time-series data for the 1980 to 2012 period and also for a panel for the ASEAN-5 countries, we found the presence of bidirectional causality between female fertility and female labour force participation. Other studies (Mishra \& Smyth, 2010; Salamaliki, Venetis, \& Giannakopoulos, 2013) concur with this results. We therefore conclude that for the ASEAN-5 countries to increase female labour force participation rate and offset fertility declines, there should be supportive policies in the form of more flexible labour market arrangements, better access to childcare and increased maternity benefits.
\end{abstract}

Keywords: female fertility, female labour force participation, causality 


\section{Introduction}

The question of whether female fertility determines labour force participation, or vice versa, has produced mixed results. The underlying reason is that women enter the labour force during their child bearing and child rearing years, which then limits the number of children they decide to have, and subsequently the family size. In turn, lower rates of fertility can free up a significant amount of women's time, thereby facilitating their entry into the labour force. As such, this paper sets out to answer the question of "What causes what?" Easterlin's theory stressed that fertility has a positive relationship with relative income of a couple. This theory focuses on two main aspects. First, it focuses on the effect of birth rates on the relative number of young adults to older adults and second, the effect of this relative number on earnings and unemployment (Brown and Norville, 2006). Alternatively, the New Home Economics theory proposed that raising children are considered as a time intensive occupation, and this in turn will increase the value of time for females (educated female), thus exerting a negative effect on fertility. This model thus establishes a link between the decisions taken on fertility and those concerning the other activities of the household, such as labour force participation and consumption (Diebolt \& Doliger, 2005).

Figure 1 below shows that female fertility is steadily declining for Malaysia, Thailand, the Philippines and Indonesia with the exception for Singapore for the period 1980-2012. (The five Association of Southeast Asian Nations, or ASEAN, are hereafter referred to as ASEAN-5). Singapore somewhat displayed an episode of increasing female fertility from 1.621 (1987) to 1.956 (1988). Overall, female labour force participation displays an increasing trend for all ASEAN-5 countries (Figure 2). Figure 3 further plots the fertility and female labour participation rates by country to provide a clear picture of how both indicators have trended over time. 


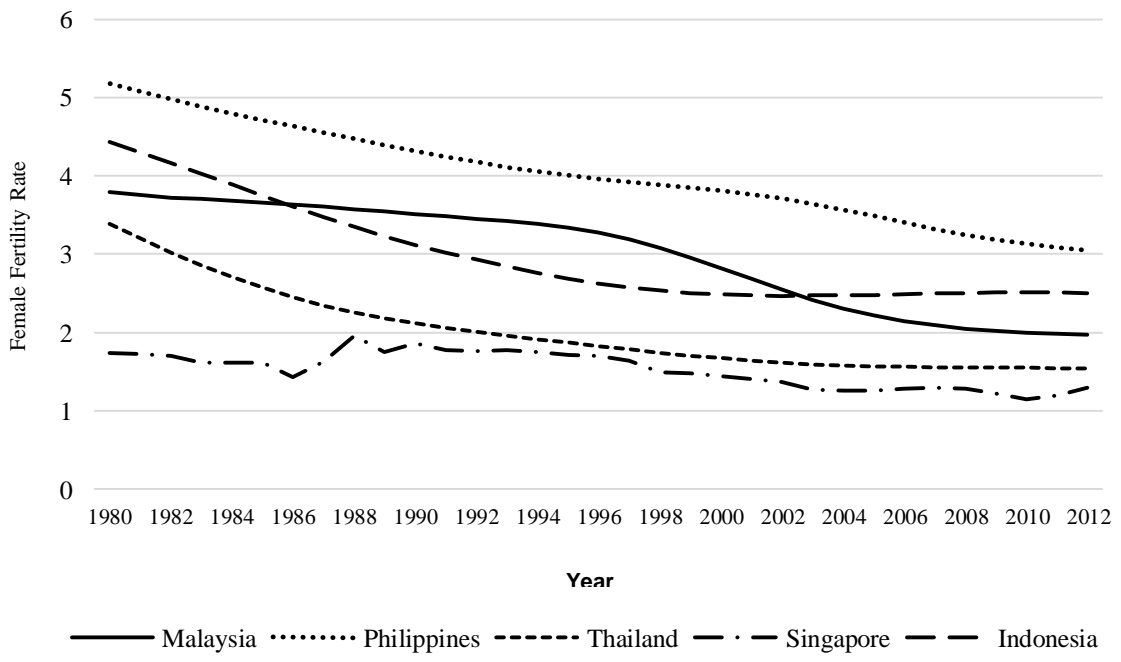

Figure 1. Female Fertility Rate in ASEAN-5, 1980-2012

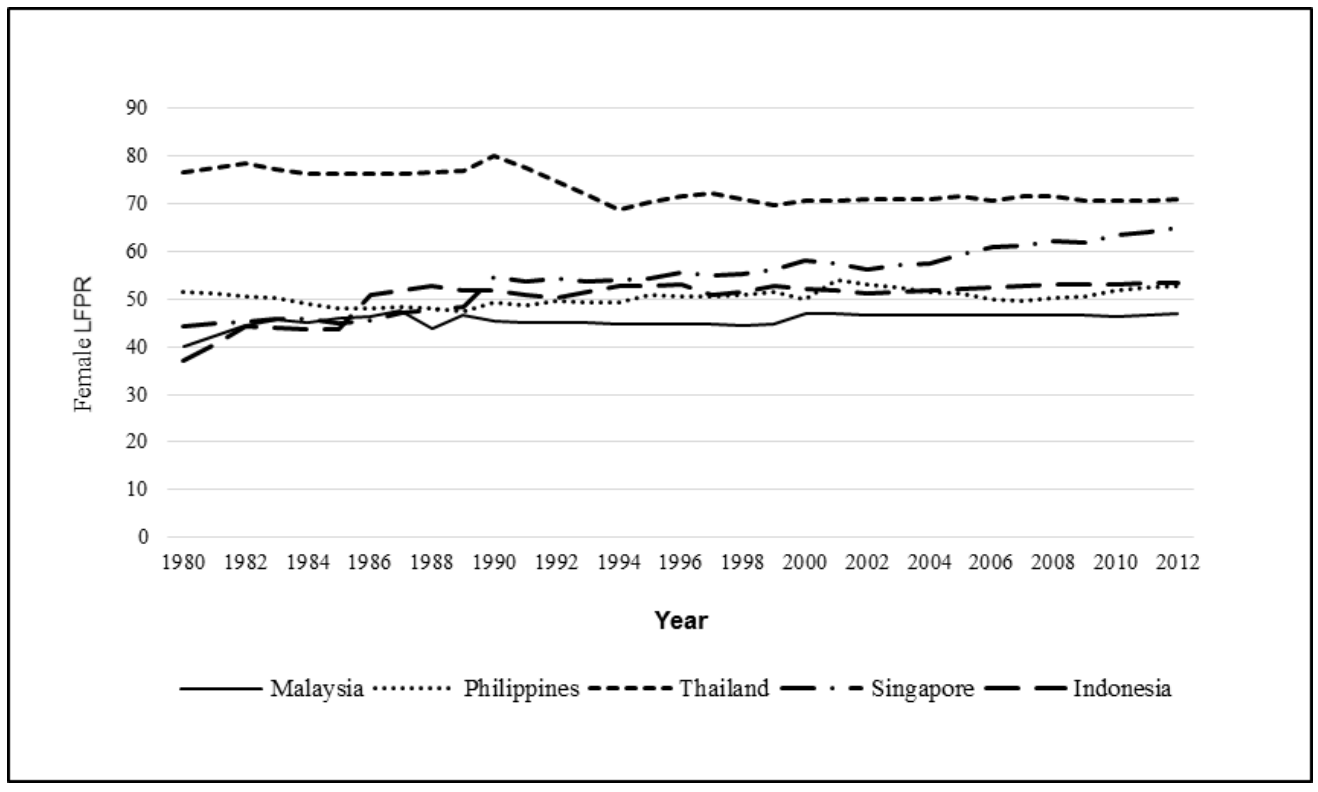

Figure 2. Female Labour Force Participation Rate in ASEAN-5, 1980-2012 


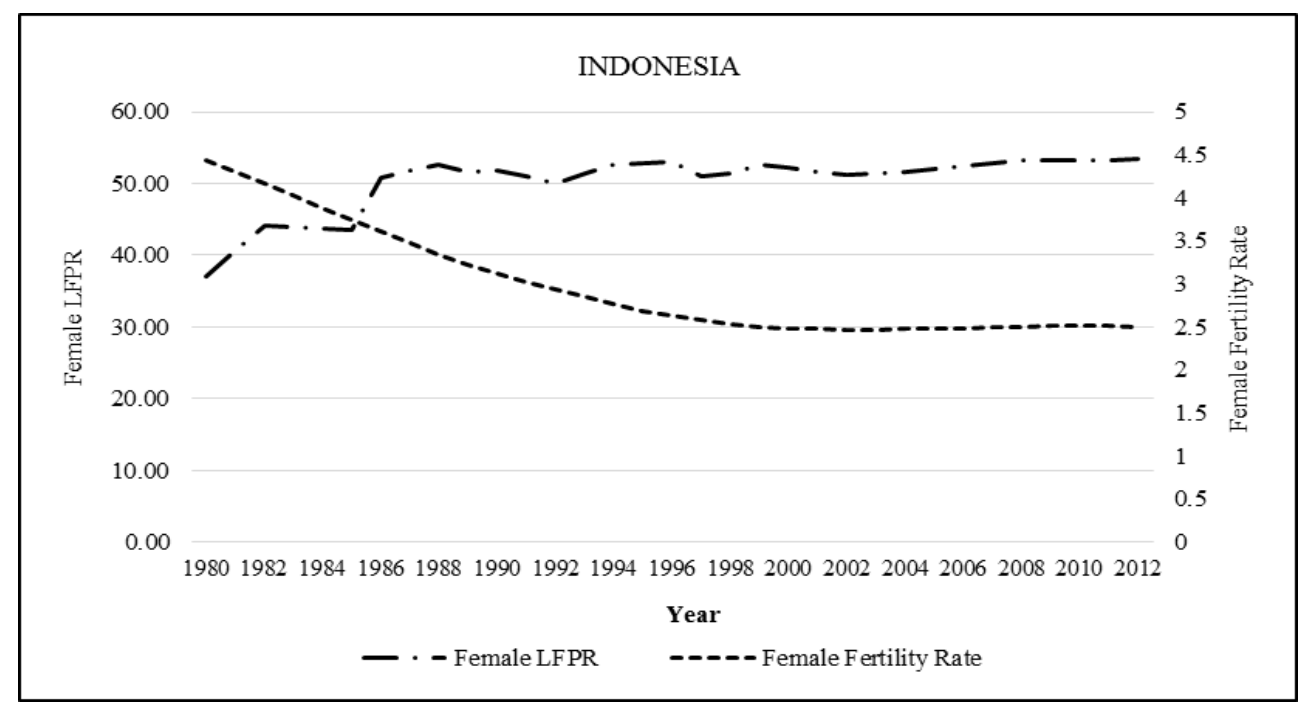

(a)

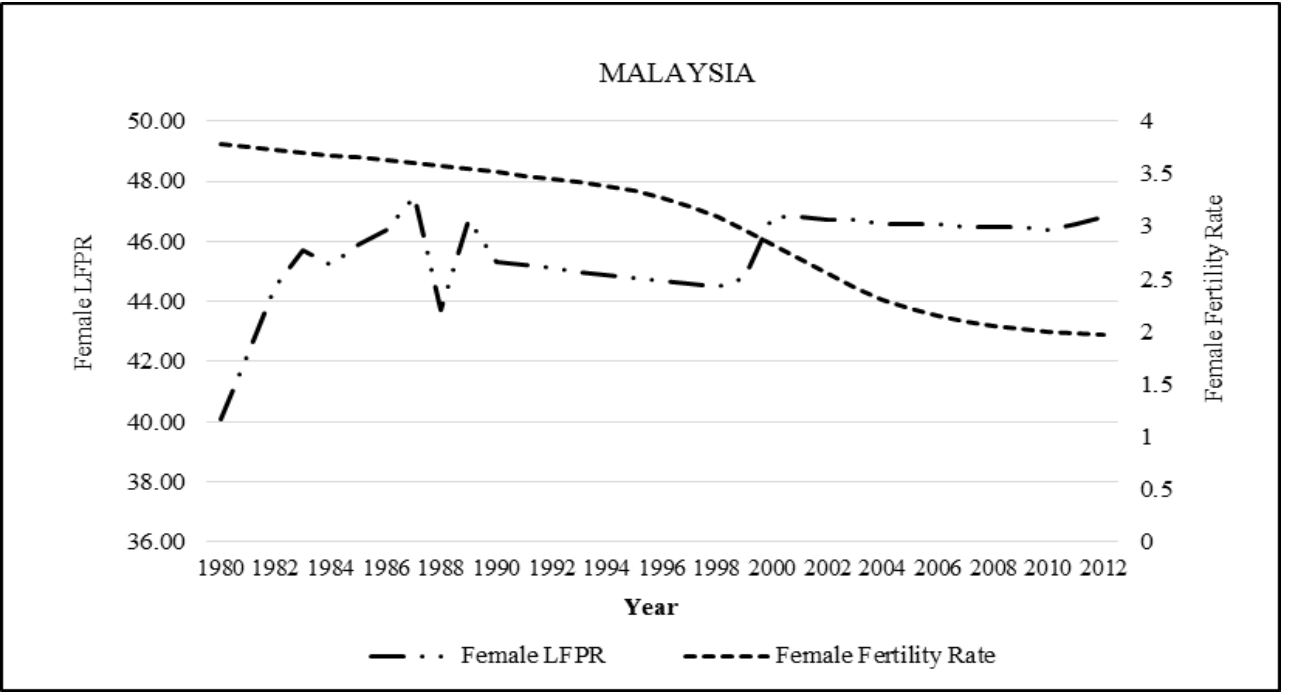

(b) 


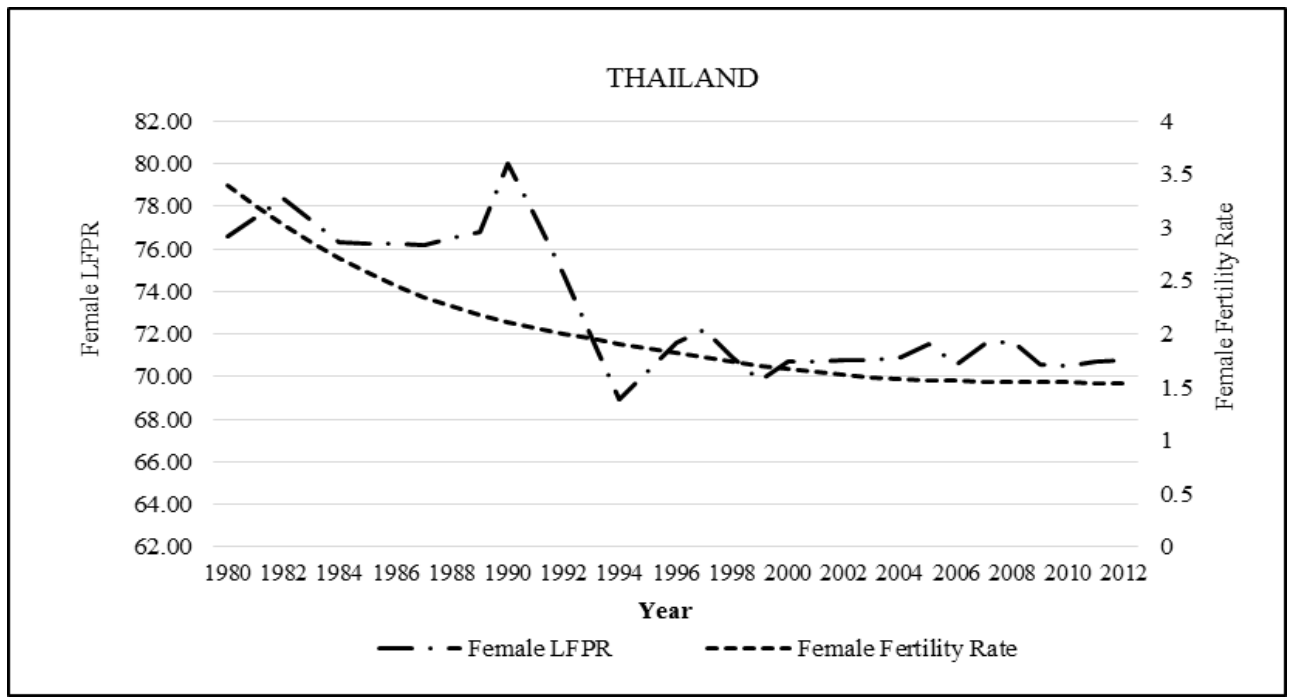

(c)

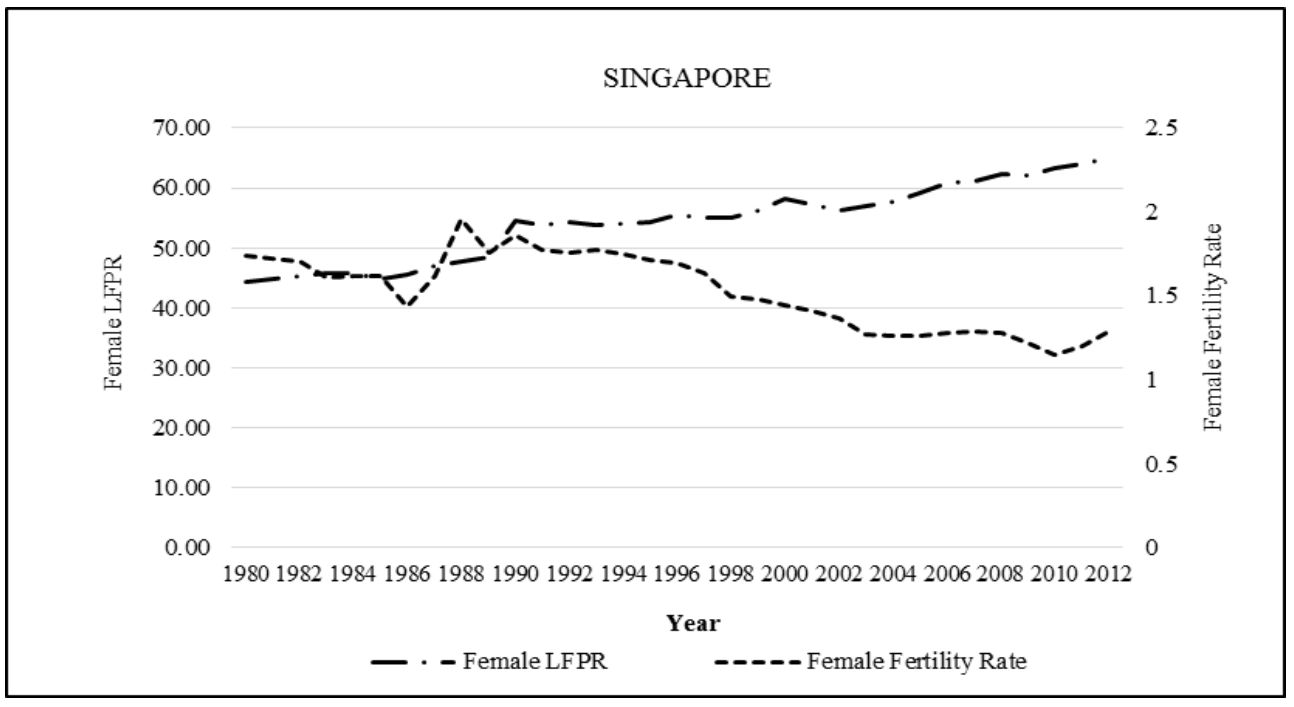

(d) 


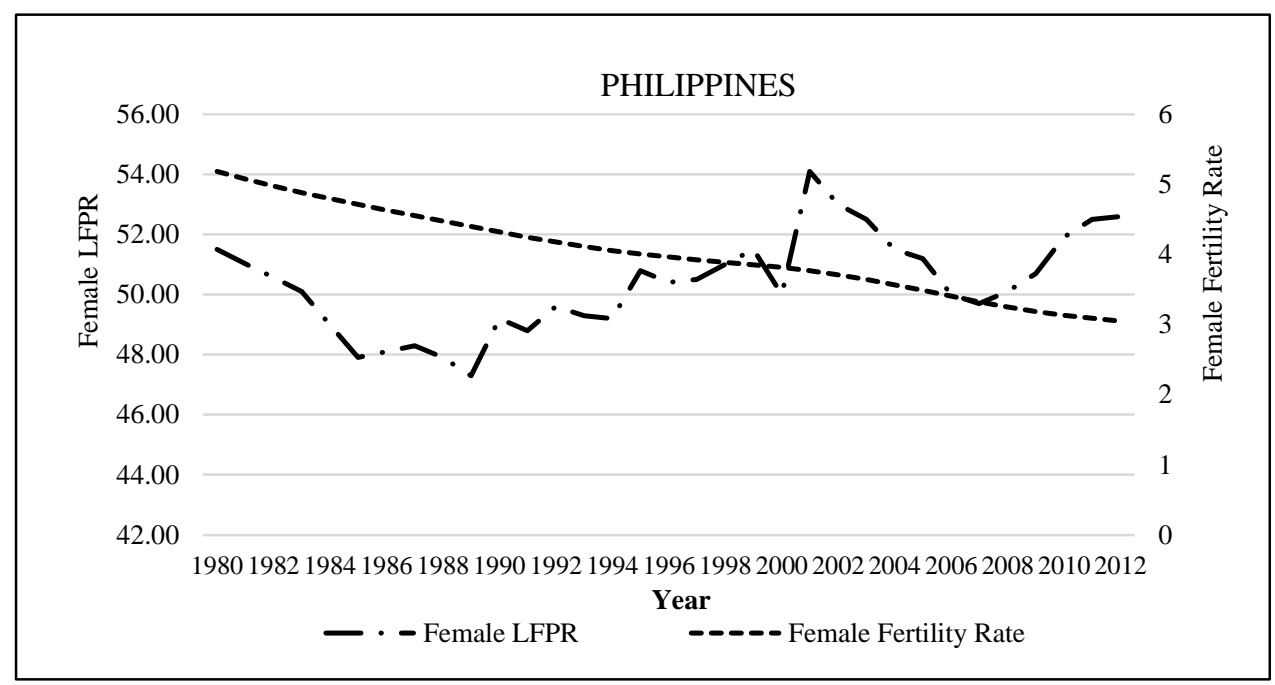

(e)

Figure 3. Female Fertility Rate and Female Labour Force Participation Rate, by Country, 1980-2012

Mahdavi (1990) proposed that an increase in the female labour force participation rate can cause a decline in fertility for industrialized countries. Narayan (2006) also showed that female labour force participation rate has an inverse relationship with female fertility for Taiwan during the period from 1966-2001. The same relationship was observed by Lee and Chung (2008) and also Chun and Oh (2002) for the case of Korea. Ahn and Mira (2002) also highlighted the negative effects of female labour force participation rate on growth of fertility rate in the case of the Organization of Economic Cooperation and Development (OECD) countries. The female labour force participation rate is also found to be negatively related to the fertility rate for Canada (McNown \& Ridao-Cano, 2004). Beguy (2009) further noted that an increase in women employment reduces female fertility in the case of Lome, while for Dakar a positive relationship was observed. An inverse relationship between female fertility and female labour force participation was also found by Bloom, Canning, Fink and Finlay (2009) for an unbalanced five-year panel covering the period from 1960 to 2000 for 97 countries. Conversely, Cheng (1996) for the case of United States argued that the female labour force participation seems not to affect the probability of fertility rate. Even though an inverse relationship is observed for many countries between female fertility and female labour force participation, Del Boca (2002) found that low labour market participation rates of married women accompanied low birth rates for Italy, as well as in other Southern European countries. 
Furuoka's (2012) findings indicated that there is no causal relationship between female fertility and female labour force participation for a panel of ASEAN-5 countries, except that the number of children is a cause of change in female labour force participation in ASEAN-5 countries in the long run. Mishra, Nielsen and Smyth (2010) found a long-run Granger causality that runs from total fertility rate to female labour force participation rate and that a 1 percent rise in total fertility rate results in a 0.4 percent reduction in female labour force participation rate for a panel of G7 countries. Cheng and Nwachukwu (1997) found that for Japan, the causality runs from female fertility to female labour force participation, where women's employment do not hinder or reduce the probability of having more children, but having small children at home can discourage women from seeking employment outside. Salamaliki et al. (2013) established a bidirectional indirect causality between female labour supply and fertility. Narayan and Smyth (2006) found that in the short run, there is unidirectional Granger causality running from fertility rate to female labour force participation while in the long run the fertility rate Granger cause female labour participation. Lau, Lee, Low, Low and Yap (2014) observed a unidirectional causality between female labour force participation and fertility for the US, whereby female labour force participation Granger causes fertility. Noraznin, Haseeb and Nira (2014) also noted from their panel causality tests, the existence of uni-directional long-run causality from fertility to female labour force participation for 6 ASEAN countries, namely Malaysia, Singapore, Philippines, Indonesia, Thailand and Vietnam.

Given the empirical literature above, this paper, first, investigates the direction of relationship between female fertility and female labour force participation for the ASEAN-5 countries using time series and panel data sets. Secondly, this paper identifies the direction of causality between female fertility and female labour force participation for ASEAN-5 using panel data sets. This paper is thus organized as follows. The second section will elaborate on the empirical strategy used in this study. The third section will focus on the results and discussion while the final section concludes.

\section{Empirical Strategy}

Time data series are collected for ASEAN-5, namely Malaysia, Singapore, Thailand, Indonesia and the Philippines. The data for the two main variables used in this analysis, female fertility rate $(F R)$ and female labour force participation rate (FLFPR) covering the period of 1980 to 2012, are obtained from the World Development Indicators CD-ROM (2014). We follow the empirical model developed by Mishra and Smyth (2010), which looked at the 
causality between FLFPR and FR for OECD countries. The bilateral estimate for this study is specified as follows

$$
\begin{aligned}
& \operatorname{lnFLFPR}_{i t}=\alpha_{0}+\alpha_{1} \operatorname{lnFR}_{i t}+\varepsilon_{t} \\
& \operatorname{lnFR}_{i t}=\beta_{0}+\beta_{1} \operatorname{lnFLFPR}_{i t}+\mu_{t}
\end{aligned}
$$

where, $\ln F L F P R$ and $\ln F R$ represent the logarithm form of female labour force participation rate and female fertility rate for ASEAN-5, respectively. Before proceeding with the panel cointegration and causality tests, we employ two panel unit root test, Im, Pesaran and Shin (2003) and Breitung (2000) tests to check the stationarity properties of the variance. The IPS statistics is asymptotically $N(0,1)$, as $T$ and $N$ goes to infinity. This test is meant to test whether the null hypothesis for each series in the panel has unit root for all cross sectional units against the alternative test that at least one of the series is stationary. To confirm the stability of panel stationarity test, we also employ the Breitung unit test, where this method requires specification of numbers of lags in each cross-section panel augmented Dickey-Fuller (ADF) regression.

Once panel unit root tests are performed and the order of the integration is determined, we proceeded to the second stage that is to identify the existence of cointegrating relationships between the variables used in the analysis. We used the Larson et al. (2001) approach to determine the linkages between FLFPR and FR for ASEAN-5. Larsson, Lyhagen and Lothgren (2001) present a maximum-likelihood based panel test for the cointegrating rank in heterogeneous panels by following the heterogeneous $\operatorname{VAR}\left(k_{i}\right)$ model as follows:

$Y_{i t}=\sum_{k=1}^{k_{i}} \Pi_{i k} Y_{i, t-k}+\varepsilon_{i t}$

where, $\mathrm{i}=1,2, \ldots ., N$. Each panel groups represent $Y_{i,-k_{i}+1} \ldots \ldots \ldots, Y_{i, 0}$ and it's considered as fixed, while the error term $\left(\varepsilon_{i t}\right)$ is independently identically distributed. Larsson et al. (2001) cointegration rank hypothesis of null hypothesis is $H(r): \operatorname{rank}(\Pi) \leq r$ and alternative hypothesis represent as $H(p): \operatorname{rank}(\Pi)=\rho$. In terms of identifying the significance stages, we will use Larsson's et al. (2001) critical values based on the rank (r), expected value 
$\mathrm{E}\left(Z_{k}\right)$ and the variance $\operatorname{VAR}\left(Z_{k}\right)$. The standardize Larsson et al. (2001) cointegration statistic which can be define as $\overline{L R}$-statistic can be define as follow

$\gamma_{\overline{L R}}\{H(r) \mid H(p)\}=\frac{\sqrt{N}\left(\overline{L R}_{N T}\{H(r) \mid H(p)\}-E\left(Z_{k}\right)\right)}{\sqrt{\operatorname{Var}\left(Z_{k}\right)}}$

We also adopt the Dynamic Ordinary Least Square (DOLS) proposed by Kao and Chiang (2000) to identify the long-run cointegration relationship. The DOLS technique provides a consistent estimate of standard errors that can be used for inference with normal limiting properties. When, FLFPR is the dependent variable, $i=1,2 \ldots . T$; the panel DOLS estimator can be rewritten as:

$\beta_{D O L S}^{\prime}=\sum_{i=1}^{N}\left(\sum_{i=1}^{T} \ln F L F P R_{i t} \ln F L F P R^{\prime}{ }_{i t}\right)^{-1}\left(\sum_{i=1}^{T} \ln F L F P R_{i t} \ln F R^{\prime}{ }_{i t}\right)$

Basically, the DOLS estimators do not give efficient estimates in the presence of unique order of integration of the variables. To solve this problem, the Fully Modified Ordinary Least Square (FMOLS) method developed by Pedroni (2001) is applied to calculate the values of long-run estimates. The FMOLS technique is known not only to generate consistent estimates in small samples but also does not suffer from large size distortions in the presence of both endogeneity and heterogeneous dynamics. To determine the long- and shortrun dynamics along with the error correction term, we employ Pesaran, Shin and Smith (1999) or known as Pooled Mean Group (PMG) estimates. The following equation represents the PMG estimates:

$\operatorname{lnFLFPR}_{i t}=\sum_{k=1}^{p} \beta_{i k} \operatorname{lnFLFPR}_{i, t-k}+\sum_{k=0}^{q} \delta_{i k} \operatorname{lnFR}_{i, t-k}+\mu_{i}+\varepsilon_{i t}$

According to the Pesaran et al. (1999), when we use PMG estimates, we need to assume that the disturbance terms will independently distribute over the groups and the mean value equal to zero, while the variance is above than zero $\left(\sigma_{i}^{2}>0\right)$. Using the PMG estimates we are able to determine the speed of adjustment, which indicates the variables archive to the long-run equilibrium 
from short-run disequilibrium conditions. From equation (7), ect $t_{-1}$ are the error correction term and the $\gamma_{i}$ represent the coefficient measuring the speed of adjustment and it must be significant with negative sign. The fixed effects error term represented by $\mu_{i}$ and $\varepsilon_{i t}$, indicate the panel error term. Thus, there exists a PMG with error correction term that can be formulated as follows

$\operatorname{lnFLFPR}_{i t}=\alpha_{1}+\sum_{k=1}^{m-1} \beta_{i k} \Delta \operatorname{lnFLFPR} R_{i, t-k}+\sum_{k=0}^{n-1} \delta_{i k} \Delta l n F R_{i, t-k}++\gamma_{i} e c t_{i, t-1}+\mu_{i}+\varepsilon_{i t}$

To test the Granger causality effects, we employ the panel causality test developed by Dumitrescu and Hurlin (2012), known as DH Granger causality test. The DH Granger causality test is a simplified version of the Granger (1969) non-causality test applicable for heterogeneous panel data models which have fixed coefficients. Under the null hypothesis of non-causality, each individual Wald statistic converges to chi-squared distribution with degree of freedom. The standardized test statistics $Z_{N, T}^{H N C}$ for $T, N \rightarrow \infty$ is as follows

$$
Z_{N, T}^{H N C}=\sqrt{\frac{N}{2 M}}\left(W_{N, T}^{H N C}-M\right) \rightarrow N(0,1)
$$

\section{Results and Discussion}

Table 1 displays the results for the panel unit root test using two methods, the IPS and Breitung tests. The results reveal that the null hypothesis of unit roots for the panel data of the female fertility and female labour force participation cannot be rejected in levels, while in first differences this hypothesis is rejected. These results indicate that both the variables under study are non-stationary in level, but emerged stationary in first differences.

Table 1. Panel Unit Root Tests

\begin{tabular}{lcccc}
\hline & \multicolumn{2}{c}{ At level } & \multicolumn{2}{c}{ At first difference } \\
\cline { 2 - 5 } & $\ln F R$ & $\ln F L F P R$ & $\ln F R$ & $\ln F L F P R$ \\
\hline IPS & -0.368 & $-2.100^{* *}$ & $-2.592^{*}$ & $-5.749^{*}$ \\
\multirow{2}{*}{ Breitung } & $(-.356)$ & $(0.017)$ & $(0.000)$ & $(0.000)$ \\
& 1.417 & -1.127 & $-7.885^{*}$ & $-4.989^{*}$ \\
& $(0.921)$ & $(0.111)$ & $(0.000)$ & $(0.000)$ \\
\hline
\end{tabular}

Note: ${ }^{*}$ and ${ }^{* *}$ significant at $1 \%$ and $5 \%$ levels respectively. The optimal lag, based on AIC and $p$-values, are in parentheses. 
Table 2 below shows the results of panel cointegration test using two methods namely Johansen Fisher cointegration (for individual countries) and also Larsson et al. (2001) heterogeneous panel cointegration (for panel of five countries). The results reveals that there are two contegrating relations for Indonesia at $5 \%$ level of significance while for remaining ASEAN countries namely Malaysia, Philippines, Singapore and Thailand there are only one cointegrating relation at $5 \%$ level of significance. The results of Larsson et al. (2001) heterogeneous panel cointegration test reveals that there is a long-run relationship between those variables over the sample period because the panel likelihood ratio is 16.392 which has exceeded the critical value of 12.53 at $5 \%$ level of significance. As such, we reject the null hypothesis of no cointegration at panel level. Based on the likelihood based panel cointegration test we can thus conclude that both female fertility and female labour force participation are cointegrated for ASEAN-5 countries.

Table 2. Cointegration Test Results

\begin{tabular}{|c|c|c|c|}
\hline \multirow[b]{2}{*}{ Country } & \multicolumn{3}{|c|}{ Johansen Fisher cointegration } \\
\hline & $r=0$ & $r \leq 1$ & Rank $(k)$ \\
\hline Indonesia & $34.963^{*}$ & $11.145^{*}$ & 2 \\
\hline Malaysia & $28.499^{*}$ & 0.162 & 1 \\
\hline Philippines & $19.805^{*}$ & 0.056 & 1 \\
\hline Singapore & $15.574^{*}$ & 0.658 & 1 \\
\hline Thailand & $50.534^{*}$ & 9.500 & 1 \\
\hline \multirow[t]{3}{*}{ Panel Fisher } & $71.83^{*}$ & $29.46^{*}$ & 2 \\
\hline & \multicolumn{3}{|c|}{ Larsson et al. heterogeneous panel cointegration } \\
\hline & $r=0$ & $r \leq 1$ & $\operatorname{Rank}(k)$ \\
\hline Indonesia & $19.897^{*}$ & $15.049^{*}$ & 2 \\
\hline Malaysia & $15.443^{*}$ & 1.466 & 1 \\
\hline Philippines & 9.453 & 1.625 & 0 \\
\hline Singapore & 6.537 & 0.720 & 0 \\
\hline Thailand & $30.627^{*}$ & $12.575^{*}$ & 2 \\
\hline$E\left(Z_{K}\right)$ & 6.086 & 1.137 & \\
\hline $\operatorname{Var}\left(Z_{K}\right)$ & 10.535 & 2.212 & \\
\hline Panel $_{L R}$ & $16.392^{*}$ & 6.287 & 1 \\
\hline$C V=5 \%$ & 12.53 & 3.84 & \\
\hline
\end{tabular}

Note: * denote statistically significant at $5 \%$. Critical value based on Larsson's et al. (2001). 
Table 3. DOLS and FMOLS Estimates

\begin{tabular}{|c|c|c|c|c|}
\hline \multirow{3}{*}{ Country } & \multicolumn{4}{|c|}{ Dependent variable: $\ln F R$} \\
\hline & \multicolumn{2}{|c|}{ DOLS } & \multicolumn{2}{|c|}{ FMOLS } \\
\hline & Coeficient & $t$-statistics & Coeficient & $t$-statistics \\
\hline Indonesia & $\begin{array}{l}-0.142^{*} \\
(0.030)\end{array}$ & -4.620 & $\begin{array}{l}-0.138^{*} \\
(0.023)\end{array}$ & -5.793 \\
\hline Malaysia & $\begin{array}{c}-0.556^{* *} \\
(0.201)\end{array}$ & -2.759 & $\begin{array}{l}-0.423^{*} \\
(0.156)\end{array}$ & -2.711 \\
\hline Phillipines & $\begin{array}{l}-0.239^{*} \\
(0.009)\end{array}$ & -2.507 & $\begin{array}{c}-0.234^{* *} \\
(0.089)\end{array}$ & -2.623 \\
\hline Singapore & $\begin{array}{l}-0.028^{*} \\
(0.009)\end{array}$ & -2.979 & $\begin{array}{l}-0.027^{*} \\
(0.008)\end{array}$ & -3.243 \\
\hline Thailand & $\begin{array}{l}0.139^{*} \\
(0.025)\end{array}$ & 5.370 & $\begin{array}{l}0.152^{*} \\
(0.026)\end{array}$ & 5.827 \\
\hline \multirow[t]{2}{*}{ PanelDOLS,FMOLS } & $\begin{array}{c}-0.869^{* * *} \\
(0.461) \\
\end{array}$ & -1.885 & $\begin{array}{c}-0.985^{* *} \\
(0.415) \\
\end{array}$ & -2.375 \\
\hline & \multicolumn{4}{|c|}{ Dependent variable: $\ln F L F P R$} \\
\hline Indonesia & $\begin{array}{l}-0.913^{*} \\
(0.313)\end{array}$ & -2.916 & $\begin{array}{l}-0.830^{*} \\
(0.241)\end{array}$ & -3.443 \\
\hline Malaysia & $\begin{array}{c}-0.611^{* *} \\
(0.288)\end{array}$ & -2.119 & $\begin{array}{l}-0.978^{*} \\
(0.340)\end{array}$ & -2.872 \\
\hline Phillipines & $\begin{array}{l}-0.409^{*} \\
(0.073)\end{array}$ & -5.602 & $\begin{array}{c}-0.511^{* *} \\
(0.221)\end{array}$ & -2.312 \\
\hline Singapore & $\begin{array}{c}-1.417^{* *} \\
(0.544)\end{array}$ & -2.604 & $\begin{array}{l}-1.440^{*} \\
(0.421)\end{array}$ & -3.420 \\
\hline Thailand & $\begin{array}{l}-3.508 \\
(7.221)\end{array}$ & 0.485 & $\begin{array}{c}4.816 \\
(7.363)\end{array}$ & 0.654 \\
\hline PanelDOLS,FMOLS & $\begin{array}{l}-0.204^{*} \\
(0.056)\end{array}$ & -3.626 & $\begin{array}{c}-0.116^{* *} \\
(0.046)\end{array}$ & -2.528 \\
\hline
\end{tabular}

Note: ${ }^{*}, * *$ and ${ }^{* * *}$ significant at $1 \%, 5 \%$ and $10 \%$ levels respectively. Standard errors are in parentheses.

Table 3 above shows the results from both DOLS and FMOLS methods. When $F R$ is used as the dependent variable, for all countries, the FLFPR is found to be significant. For most ASEAN-5 countries, with the exception for Thailand, a negative relationship can be observed, which concurs with the theory and also findings from many other researchers. On the other hand, when FLFPR is used as the dependent variable, a negative relationship can be observed for most ASEAN-5 countries, except for Thailand (see also Figure 3 and Haseeb, Noraznin, \& Nira [2015]). However, for Thailand, using both DOLS and FMOLS methods, we found that female fertility is not significant. The ambiguity in the fertility-female labour force participation rate for Thailand 
warrants further analysis. Subsequently, panel DOLS and panel FMOLS were constructed, and we found that a negative relationship can be observed for the panel dataset.

Table 4 displays the results for the estimation of PMG for long-run and shortrun coefficients of the female fertility and female labour force participation with their respective adjustment coefficients. The cointegration is performed following Pesaran et al. (1999). For the female fertility equation, the adjustment coefficient produced the expected sign and is significant at the 1 percent level. For the female labour force participation equation, the coefficient of adjustment has the expected sign but is only significant at the 10 percent level. This result reveals that there is an adjustment dynamic from short-run to longrun equilibrium. When the long-run coefficients are considered, significant coefficients are obtained for both equations. Using the PMG for fertility equation, the coefficient obtained is -0.157 , while for female labour force participation, the coefficient obtained is -0.048 . The Hausman test results indicate that in both cases, restriction of homogeneity in the long-run is not rejected at the 1 percent significance level.

Table 4. Heterogeneous Panel Cointegration Test

\begin{tabular}{|c|c|c|c|c|}
\hline & \multicolumn{2}{|c|}{ Dependent variable: $\ln F R$} & \multicolumn{2}{|c|}{ Dependent variable: $\ln F L F P R$} \\
\hline & MG & PMG & MG & PMG \\
\hline & \multicolumn{4}{|c|}{ Panel 1: Long-run estimates } \\
\hline $\ln F R$ & & & $\begin{array}{l}-0.106^{*} \\
(0.020)\end{array}$ & $\begin{array}{c}-0.048 * * \\
(0.021)\end{array}$ \\
\hline \multirow[t]{2}{*}{$\ln F L F P R$} & $\begin{array}{c}-0.264^{*} \\
(0.018)\end{array}$ & $\begin{array}{l}0.157 * \\
(0.015)\end{array}$ & & \\
\hline & \multicolumn{4}{|c|}{ Panel 2: Short-run estimates } \\
\hline $\ln F R$ & & & $\begin{array}{c}0.203 \\
(0.259)\end{array}$ & $\begin{array}{c}0.205 \\
(0.288)\end{array}$ \\
\hline $\ln F L F P R$ & $\begin{array}{c}0.143 \\
(0.146)\end{array}$ & $\begin{array}{c}0.146 \\
(0.149)\end{array}$ & & \\
\hline ect $t_{t-1}$ & $\begin{array}{c}-0.066 * * * \\
(0.035)\end{array}$ & $\begin{array}{c}-0.061 * * * \\
(0.035)\end{array}$ & $\begin{array}{c}-0.325^{*} \\
(0.095)\end{array}$ & $\begin{array}{c}-0.282 * \\
(0.104)\end{array}$ \\
\hline Hausman test & \multicolumn{2}{|c|}{$0.130[0.722]$} & \multicolumn{2}{|c|}{$0.130[0.359]$} \\
\hline
\end{tabular}

To test for causality for panel data, we use the DH Granger causality test. Table 5 reports the results from the DH Granger causality test. This test can be used even under the conditions of cross-sectional dependence (Akbas, Senturk, 
\& Sancar, 2013). Bidirectional causality was found between female fertility and female labour force participation for ASEAN-5. This result contradicts with the findings by Furuoka (2012), where he found that there is no causal relationship between female labour force participation and total fertility rate, except that the number of children is a cause of change in female labour force participation in ASEAN-5 countries in the long run.

Table 5. DH Granger Causality Test

\begin{tabular}{llcc}
\hline Direction of causality & $W^{D H}$ & $Z^{D H}$ & $p$-value \\
\hline $\ln F R \rightarrow \ln F L F P R$ & $4.645^{*}$ & $4.967^{*}$ & 0.000 \\
$\ln F L F P R \rightarrow \ln F R$ & $2.987^{*}$ & $2.661^{*}$ & 0.007 \\
\hline
\end{tabular}

Note: ${ }^{*}$ denote statistically significant level at $1 \%$.

\section{Conclusion}

This paper established the existence of cointegration for individual ASEAN-5 countries using time-series data and also for ASEAN in a panel context. Further, the Granger Causality test results using panel data for ASEAN-5 countries revealed bidirectional causality between female fertility and female labour force participation, thus validating findings in many other studies such as in studies done by Mishra and Smyth (2010) for OECD countries and also Salamaliki et al. (2013) for the United States. The findings of this study, though contradicts with the findings by Furuoka (2012), are considered more robust and reliable. As such, we conclude that for the ASEAN-5 countries, female labour supply is both a driver and an outcome of declining fertility. Ultimately, female labour force participation will increase with higher educational attainment and better opportunities to work in a modern economy. Thus, to arrest declining fertility, the State should provide flexible labour market arrangements, better access to childcare, increase maternity benefits as well as provide for other supportive institutions and legal measures to improve work-life balance and ease the burden of domestic duties.

\section{Acknowledgments}

The authors wish to thank the University of Malaya for the financial support provided under the University of Malaya Research Grant (RG265-11HNE). This is a revised version of the paper presented at the 4th International Conference on Management, Finance \& Entrepreneurship (ICMFE-2015), Medan, Indonesia from 11-12 April 2015. 


\section{References}

Ahn, N. \& Mira, P. (2002). A note on the changing relationship between fertility and female employment rates in developed countries. Journal of Population Economics, 15(4), 667-682.

Akbas, Y. E., Senturk, M., \& Sancar, C. (2013). Testing for causality between the foreign direct investment, current account deficit, GDP and total credit: EvFDInce from G7. Panoeconomicus, 60(6), 791-812.

Beguy, D. (2009). The impact of female employment on fertility in Dakar (Senegal) and Lome (Togo). Demographic Research, 20, 97-128.

Bloom, D. E., Canning, D., Fink, G., \& Finlay, J. E. (2009). Fertility, female labor force participation and the demographic dividend. Journal of Economic Growth, 14(2), 79-101.

Breitung, J. (2000). The local power of some unit root tests for panel data. In B. Baltagi (Ed.), Nonstationary panels, panel cointegration, and dynamic panels (pp. 161-178). Amsterdam: JAI Press.

Brown, R. L., \& Norville, C. (2006). Theories of fertility. Retrieved from https://uwaterloo.ca/waterloo-research-institute-in-insurancesecurities-and-quantitative-finance/sites/ca.waterloo-research-institutein-insurance-securities-and-quantitative-finance/files/uploads/files/0106.pdf

Cheng, B. S. (1996). An investigation of cointegration and causality between fertility and female labor force participation. Applied Economic Letters, 3(1), 29-32.

Cheng, B. S., \& Nwachukwu, S. L. S. (1997). The effect of education on fertility in Taiwan: A times series analysis. Economics Letters, 56(1), 95-99.

Chun, H., \& Oh, J. (2002). An instrumental variable estimate of the effect of fertility on the labor force participation of married women. Applied Economics Letters, 9(10), 631-634.

Del Boca, D. (2002). Low fertility and labour force participation of Italian women: Evidence and interpretations. OECD Labour Market and Social Policy Occasional Papers, No. 61, Paris: OECD Publishing. Retrieved from http://dx.doi.org/10.1787/263482758546

Diebolt, C., \& Doliger, C. (2005). Becker vs. Easterlin education, fertility and growth in France after World War II. Retrieved from http://iussp2005.princeton.edu/papers/50088

Dumitrescu, E. I., \& Hurlin, C. (2012). Testing for Granger non-causality in heterogeneous panels. Economic Modelling, 29(4), 1450-1460. 
Furuoka, F. (2012). Female labour force participation and total fertility rate: New evidence from ASEAN countries. Actual Problems of Economics, 135(9), 542-552.

Granger, C. W. J. (1969). Investigating causal relations by econometric models and cross-spectral methods. Econometrica, 37(3), 424-438.

Haseeb, M., Noraznin, A. B., \& Nira, H. H. (2015). The nexus between female labour force participation (FLFP) and fertility rate in selected ASEAN countries: Panel cointegration approach. Modern Applied Science, 9(8), 29-39.

Im, K. S., Pesaran M. H. \& Shin, Y. (2003). Testing for unit roots in heterogeneous panels. Journal of Econometrics, 115(1), 53-74.

Kao, C., \& Chiang, M. H. (2000). On the estimation and inference of a cointegrated regression in panel data. Advanced Econometrics, 15, 179222.

Larsson, R., Lyhagen, J., \& Lothgren, M. (2001). Likelihood-based cointegration in heterogeneous panel. The Econometrics Journal, 4(1), 109-142.

Lau, T. Y., Lee, K. Z., Low, B. L., Low, S. W., \& Yap, C. K. (2014). The impact of infant mortality rate and female labour force participation on fertility rate in United States. Unpublished Research Project for Bachelor of Economics (Financial Economics), Faculty of Business and Finance, Universiti Tunku Abdul Rahman, Kampar, Malaysia.

Lee, N., \& Chung, J.-S. (2008). Interrelation between fertility and female labor force in Korea. Journal of Applied Business Research, 24(4), 139-151.

Mahdavi, S. (1990). A simultaneous-equations model of cross-national differentials in fertility and female labour force participation rates. Journal of Economic Studies, 17(2), 32-49.

McNown, R., \& Ridao-Cano, C. (2004). The effects of child benefit policies on fertility and female labor force participation in Canada. Review of Economics of the Household. 2(3), 237-54.

Mishra, V., \& Smyth, R. (2010). Female labor force participation and total fertility rates in the OECD: New evidence from panel cointegration and Granger causality testing. Journal of Economics and Business, 62(1), 48-64.

Mishra, V., Nielsen, I. L., \& Smyth, R. L. (2010). On the relationship between female labour force participation and fertility in G7 countries: Evidence from panel cointegration and Granger causality. Empirical Economics, $38(2), 361-372$. 
Narayan, P. K. (2006). Determinants of female fertility in Taiwan, 1966-2001: Empirical evidence from cointegration and variance decomposition analysis. Asian Economic Journal, 20(4), 393-407.

Narayan, P. K., \& Smyth, R. (2006). Female labor force participation, fertility and infant mortality in Australia: Some empirical evidence from Granger causality tests. Applied Economics, 38(5), 563-572.

Noraznin A. B., Haseeb, M., \& Nira, H. H. (2014). The dilemma of female labour force participation (FLFP) and fertility rate in Asian-6 countries: A panel cointegration approach. Life Science Journal, 11(8), 584-590.

Pedroni, P. (2001). Purchasing power parity tests in cointegrated panels. Review of Economics and Statistics, 83(4), 727-731.

Pesaran, H., Shin, Y., \& Smith, R. (1999). Pooled Mean Group estimation and dynamic heterogeneous panels. Journal of the American Statistical Association, 94(446), 621-634.

Salamaliki, P. K., Venetis, I. A., \& Giannakopoulos, N. (2013). The causal relationship between female labor supply and fertility in the USA: Updated evidence via a time series multihorizon approach. Journal of Population Economics, 26(1), 109-145.

Date Received: 15 November 2017 Date of acceptance: 15 April 2018 